\title{
"I CAN(NOT) DRAW": THE USE OF VISUAL METHODS IN RESEARCH ON TAX ADMINISTRATION REFORM AND CORRUPTION
}

\author{
Gusti Ayu Indah Ratnasari, \\ Polytechnic of State Finance STAN
}

Alamat Korespondensi: gusti.ratnasari@pknstan.ac.id

\section{INFORMASI ARTIKEL}

Diterima Pertama

[17 02 2020]

Dinyatakan Diterima

[24 02 2020]

KATA KUNCl:

Visual methods, tax reform, corruption, projective drawing, photo elicitation, organisational change

KLASIFIKASI JEL: $\mathrm{M} 00, \mathrm{ZOO}$

\begin{abstract}
ABSTRAK
Images have been used in other studies to investigate organisational change, although far less common than the interview as a method. However, images have rarely, if ever, been used to study tax reform and corruption. This article focuses on the assessment of visual methods, using empirical data which are drawn from a wider study of the interplay between organisational change and corruption, an issue which is still underexplored. Using the Indonesian tax administration reform in the 2000s as a case study, the study employs visual methods (drawings and photographs), the interviews and focus group discussions to collect the data, which are analysed thematically.

The assessment on the visual data shows that this article confirms the existing literature on the values of images in stimulating responses, conveying complex ideas and drawing out paradoxical emotions toward organisational change. Additionally, there is a potential ability of images to unveil the 'dark side' of organisational change and its management. Despite the benefits of visual methods, this article also provides evidence on the drawbacks of using images and recommendations for future research.
\end{abstract}

Gambar telah digunakan sebagai metode penelitian dalam beberapa studi tentang perubahan organisasi, meskipun penggunaannya jauh lebih jarang daripada wawancara. Namun, gambar sangat jarang, bahkan belum pernah, digunakan untuk meneliti reformasi pajak dan korupsi. Fokus dari artikel ini adalah pada evaluasi atas metode visual, dengan menggunakan data empiris dari studi yang lebih luas tentang interaksi antara perubahan organisasi dan korupsi, di mana hal ini merupakan suatu topik yang penelitiannya masih sangat terbatas. Dengan menggunakan reformasi administrasi perpajakan Indonesia pada tahun 2000-an sebagai studi kasus, studi ini menggunakan metode visual (gambar dan foto), wawancara, dan diskusi kelompok terpumpun (atau focus group discussion) untuk mengumpulkan data yang dianalisis secara tematik.

Evaluasi atas data visual menunjukkan bahwa artikel ini mendukung literatur yang ada tentang kemampuan gambar dalam menstimulasi respon, menyampaikan ide-ide kompleks, dan menggambarkan emosi paradoks atas perubahan organisasi. Selain itu, terdapat potensi kemampuan gambar untuk mengungkap 'sisi gelap' dari perubahan organisasi dan manajemen perubahan. Terlepas dari manfaat metode visual, artikel ini juga memberikan bukti empiris tentang kelemahan penggunaan gambar dan rekomendasi untuk penelitian selanjutnya. 


\section{INTRODUCTION}

"The fight against corruption and the reform of the state are two sides of the same coin."

Links have been drawn between public sector reforms and (the fight against) corruption. For example, in Tanzi's (1998, p. 589) work, as quoted above. He asserts that they are aspects of the same fight, not distinct and independent from each other. Various scholars suggest different kinds of reforms to reduce corruption, including tax administration reform. Corruption is believed to be associated with the activities of government, such as taxation, since the tax agency has a high degree of discretion and frequent encounters with the public (Tanzi, 1998). While reforming the tax administration is often proposed as a way to reduce corruption, the results are mixed (Bridi, 2010; Fjeldstad, 2003, 2005; Kaufmann, 1997; Wihantoro, 2012; Zuleta, 2008).

Despite the potential link between the two phenomena, it is surprising that the literature on public-sector change has not adequately addressed corruption as a contextual background. To fill the gap, a research study, from which the data of this article are drawn, has been conducted. The study aims to provide empirical evidence of the interplay between organisational change and corruption, using a case study of the Indonesian tax administration reform. The case organisation initiated a tax administration reform in the 2000s and experienced problems with corruption before and after the reform (Rizal, 2011). Considering the context of and problem in the case organisation, researching corruption using the Indonesian tax administration reform as a case study will obtain a rich and in-depth understanding of the research context (Eisenhardt \& Graebner, 2007) and real-life phenomenon (Yin, 2009).

In the case study strategy, it is likely that the researchers employ different techniques of data collection, which is referred to as triangulation (Saunders, Lewis, \& Thornhill, 2012). Consequently, this study uses different methods in collecting the data, including semi-structured interviews, focus groups and visual methods. Image-based methodologies are well rooted in sociology and anthropology (Weber, 2008) but are rarely employed in organisational studies (Kearney \& Hyle, 2004; Warren, 2009). However, organisational researchers show an increasing interest in this method (Shortt \& Warren, 2019; Vince \& Warren, 2012).

This article will focus on the assessment of visual methods in the study of tax administration reform and corruption, since there has been a dearth of research on the use of visual methods in these areas. In addition to triangulation, due to the sensitivity of corruption as a topic, and the difficulties respondents may have in talking about it, visual methods were employed to gather the data, in addition to the interviews. It was expected that images would reveal the unsaid (Vince \& Broussine, 1996). Images have been used in other studies to investigate organisational change, although far less common than the interview as a method. However, images have rarely, if ever, been used to study corruption and tax reform.

The next section will discuss the literature review on visual methods, especially drawings and photographs. Following the literature review is a presentation of the methods that were used to collect and analyse the data. Subsequently, there is a discussion about the findings, which is presented in parallel with the assessment of the values of visual methods. The last section will present the summary and recommendations for future research.

\section{LITERATURE REVIEW}

\subsection{Visual methods}

Visual methods suggest using "pictures, diagrams, computer graphics and other visual display in representing information" (Meyer, 1991, p. 78). According to Warren (2009, p. 566), the images used include "drawing, photography, video, film and Internet pages." The images function as the data source or a means to generate data or both (Warren, 2009).

The use of art as a research method, as maintained by Broussine (2008, p. 78),

enables people to communicate multifaceted information and feelings about their experience in organisations and other social settings. It legitimises the expression of complex, subtle and possibly irrational facets of organisational experience.

For example, Vince \& Broussine (1996) use drawings in their study as the catalyst to say the unsaid; that allows their research participants (managers of public service institutions) to pull out paradoxical emotions towards change management in the organisations.

In addition, it is believed that visual methods can integrate visual and verbal data (Broussine, 2008), which can be a useful form of triangulation (Meyer, 1991). For instance, Kearney \& Hyle's (2004) study on leadership change in a branch campus of a technology training school in the United States finds that drawings powerfully confirm the participants' verbal reports as well as observations which were done at the school venue. However, they suggest that despite the benefit of establishing a quicker path to the participants' emotive experiences, researchers who use visual methods, in particular drawings, may encounter participants who are reluctant to produce images.

Kearney \& Hyle (2004) also caution against independently interpreting the images without participants' commentary. Similarly, Vince \& Warren (2012) maintain that unlike in art therapy, the participant's image that is used in research is not the central point. Broussine $(2008$, p. 78$)$ asserts that

the production of images by whatever means is not usually the be-all-and-end-all of the research. It is the dialogue, reflection and sense-making that is provoked in an individual or in a group by the 
production of expressive images that can be as important as the images themselves'.

For those reasons, the design of visual methods in several studies (Allen, 2011; Barner, 2008; Broussine, 2008; Eilam \& Shamir, 2005; Kearney \& Hyle, 2004; Packard, 2008; Vince \& Broussine, 1996; Ward, 2009; Warren, 2002) included the interviews or discussion sessions, either individually or in a group. Since images are interpreted differently by different individuals, incorporating visual methods with the interview will allow the researcher to understand how images possess meaning in two levels, i.e., when the images are taken and when the interviews or discussions are held (Pink, 2013).

The types of visual methods that are utilised in this study are drawings and participant-led photography. Both methods allow the participants to co-create the qualitative data (Vince \& Warren, 2012), i.e., to cooperate with the researcher in producing and/or viewing the pictures (Warren, 2009). Pink (2013) believes that this collaborative approach is ethically a more appropriate one, as both parties "invest in, and are rewarded by, the project" (p. 65); whereas participants in conventional question and answer approaches gain little in return (Vince \& Warren, 2012). However, the collaborative approach also raises ethical questions on issues such as the anonymity of people or places that appear on the photographs and copyright of the images produced (Warren, 2002, 2009). These issues will be discussed in more detail in the following sections.

\subsection{Drawing}

The literature suggests that drawing: (1) can serve as an icebreaker that makes the research situation less rigid or formal, and a stimulus for discussion or conversation (Ward, 2009); (2) affords participants "every opportunity to frame their own experiences, unencumbered by our biases about people and organisational change" and assist them to make sense of their responses (Kearney \& Hyle, 2004, p. 362); and (3) uncovers and captures change aspects that hardly ever emerge, but are always present (Vince \& Warren, 2012). Furthermore, Kearney \& Hyle (2004, p. 380) maintain that drawings "create the opportunity for meaningful and honest verbal reports - arguably the methodology helped participants reveal more than what may have been captured with only the unstructured verbal interview."

However, as Broussine (2008) cautions, although producing arts is 'engaging and hands-on' (p.78), some participants may resist, because they are anxious about their graphic (Ward, 2009) or artistic aptitude (Kearney \& Hyle, 2004). Vince \& Warren (2012) maintain that this may occur even though participants are explained that the involvement in the research process does not require artistic ability. Nonetheless, Broussine (2008) advises that the researcher can still learn something even from such refusal. Thus, Vince and Warren (2012, p. 290) suggest the importance of utilising "what is produced, however it looks."
Another consideration is associated with the potential ability of drawing to release messy emotions (Warren, 2009) or spark unpredictable emotional reactions (Vince \& Warren, 2012). Although this affirms the strength of visual methods to explore things in a different way, it also raises an ethical issue (Warren, 2009). Vince \& Warren (2012) suggest seeking consent from the research participants, although "it is not possible to fully explain what the experience itself may reveal" (p. 286). To minimise this risk, they point out that in employing this method, it is essential to draw a line between the use of drawing in therapy and as a research method.

In spite of that, Warren (2009) advises that the implication of this issue on researchers as well as participants should not be disregarded. She goes on to say that "on account of its technological bases and assumed relationship with reality, the photograph may be seen as a more credible research method than the use of drawing" (p. 575). Due to the likelihood of resistance from the participants and the ethical issue mentioned above, another visual method, i.e., photograph, is also used in this study, in addition to drawing. The next section will explain the method.

\subsection{Photo Elicitation}

Pink (2013) identifies different uses of photographs in research. They include photographs that are taken by the researcher, collaboratively by the researcher and participants, or by the participants themselves. In one of her studies, Warren (2002) was initially taking photographs of her participants' work environment, then decided to give the camera to the participants. In this sense, "it is the participants' subjective perspective that is foregrounded, rather than the researcher's assumptions about what might be important" (Vince \& Warren, 2012, p. 281).

Previous studies combined the photograph method with the interview. In the interview, the participants are mainly asked to explain the reasons for taking the particular photographs as well as the meaning and the significance of the images (Vince \& Warren, 2012). Allen (2011) argues that asking for explanations from the participants is necessary, since it enables the researcher to grasp the significance of what is represented by the pictures. What is more, combining the photographs with the interview is believed to be "a way to uncover as much information as possible, opening up avenues and uncovering local knowledge which might have been previously unknown to the researcher" (Packard, 2008, p. 65). Unlike in semi-structured interviews, the participants of the photograph method have greater control in determining the interview structure, since they are the ones who choose what images are to be produced and viewed for the discussion (Allen, 2011; Vince \& Warren, 2012).

Another benefit of photography as a research method, as maintained by Vince \& Warren (2012), is it removes observation, as it provides access to contents that cannot be entered by the researcher (Pink, 2013). 
In addition, photographs function as the focus of the interview (Allen, 2011), generate discussions (Vince \& Warren, 2012) and help establish relationships with the participants (Pink, 2013).

Nonetheless, as Meyer (1991, p. 231) maintains, "all methods are flawed", including the visual methods. In relation to the photograph method, the first issue is associated with the ownership of the photographs. Pink (2013) argues that in some cases, the researcher and the participant may jointly own the images. However, Warren (2002) believes that in the context of research, the participant holds the copyright on the photographs, since she or he is the one who takes the images. Pink (2013) suggests clarifying the issue of ownership with the participants before the photographs are taken.

Another consideration is related to ethics. Pink (2013) emphasises asking consent from the people being photographed or official permission if necessary. In order to protect anonymity of people or places that appear on the images, Warren (2002) suggests obscuring the faces, places or any organisational features (such as logos or trade-marks), if the images are going to be used in written reports or other publications. The next section examines the methods used to collect and analyse the data.

\section{RESEARCH METHODS}

\subsection{Selecting Participants}

The Indonesian Tax Authority or Directorate General of Taxes (DGT) has more than 40,000 employees. How would participants be selected from this number of employees? Unlike quantitative research, representativeness is not the criteria in selecting the participants in this study (Bell, Bryman, \& Harley, 2018) because the research does not aim to generalise findings from the samples to the population of employees. Instead, the participants were purposefully selected based on their potential in contributing to the understanding of the research questions and objectives (Bell et al., 2018; J. D. Creswell, 2009; J. W. Creswell \& Creswell, 2017; Tracy, 2019).

Accordingly, some of the participants who were expected to be able to provide a rich explanation on the problem, are those directly involved in the reform program. In addition, as understood from the literature, different people view corruption and change differently. Consequently, the other participants in this study came from different levels of the organisational hierarchy and different divisions at different types of tax offices, from the Head Office, regional offices and local tax offices. The participants included Directors, Deputy Directors, managers (middle and lower levels) and staff members. The staff members at the regional and local

\footnotetext{
${ }^{1}$ Account representatives are officers at tax offices whose primary responsibilities are to monitor taxpayers' compliance and to provide advice, guidance and consultation to taxpayers.
}

tax offices included account representatives ${ }^{1}$, tax objection reviewers ${ }^{2}$, tax auditors ${ }^{3}$ and other staff who are responsible for clerical works.

In total, there were 21 interview participants, 21 drawing participants (who were divided into two focus group discussions; one group consisted of the head of tax offices and the other group consisted of staff members), and two photograph participants. Participants who did the interviews were different from those who participated in the focus groups. The methods which were employed to collect the data from the interviews, drawings and photographs will be explained in the following section.

\subsection{Data Collection}

This study utilised drawings and participant-led photography as data collection methods, in addition to the interviews. The drawing method was conducted in focus groups. Ward (2009) finds that the setting provided by the focus group is suitable for the utilisation of a projective drawing method. The procedure that is used in this study is following Broussine's (2008) suggestion, which involved four phases:

a. First of all, the researcher asked each participant to produce a drawing that described her or his view on the organisational change (i.e., the reformation) and corruption in the organisation.

b. After the participants finished their drawings, the researcher asked each participant to reflect on her or his drawing by writing down on the back of the picture 'words or short phrases which came to mind' when the participant looked at the image (Broussine, 2008, p. 82).

c. In the next stage, all participants worked as a whole group. In this stage, each participant was asked to show her or his picture to the group in turn. The other group members were then asked to interpret and tell the meaning that they drew from the image displayed. Next, the participant was asked to comment on her or his own picture.

d. The final phase was a group review on what has been learned by the participants, their feelings about the things that have arisen from the process and also on the process itself.

In addition to the drawing technique, this study utilised the photograph method. The participants were asked to take a set of photographs of objects, places, people or situations that represent their views on the organisational change (i.e., the reformation) and corruption in the organisation. They were issued with a digital camera, or they could use their own devices, e.g., digital cameras, mobile phones or tablets if they prefer. They were given one week to take the photographs (Allen, 2011). The photographs were

\footnotetext{
${ }^{2}$ Objection reviewers are officers whose task are to review taxpayers' objections, requests of reduction or elimination of tax administrative sanctions, and requests of reduction or cancellation of tax assessment letters.

${ }^{3}$ Tax auditors are officers who perform tax audits.
} 
viewed and discussed by each participant with the researcher in qualitative interview sessions (Allen, 2011; Packard, 2008; Pink, 2013; Vince \& Warren, 2012; Warren, 2002). The viewing was done after the images were downloaded to a laptop computer (Vince \& Warren, 2012). Alternatively, during the interview, the pictures were shown on the participants' devices, when the participants did not give consent to download the images.

The researcher let the participants decide which image they would like to show first. Thus, participants in this method have more control in structuring the discussion in the interview session. After being shown and explaining the meaning of the images, the researcher asked further questions like when, where or why the pictures were taken, the significance of the images and other questions related to the images. At the end of the session, the researcher asked about their views or feelings that had not been captured in the images as well as their feedback on the method.

At the end of the data collection stage, there were 21 interview transcripts, 21 drawings (from two focus groups) and ten photographs (from two participants). The next section will present how the data were analysed.

\subsection{Data Analysis}

There has not been much literature on the analysis of materials produced within visual research (Pink, 2013; Shortt \& Warren, 2019; Vince \& Warren, 2012). Due to the shortage, Allen (2011) built her own framework of visual data analysis. After transcribing the interviews, she looked for common issues. She added another step of analysis by "reading the transcripts alongside the photographs to understand how participants' words shed light on images' meanings" (p. 491). The current study adopted Allen's (2011) analytical framework. Since the thematic analysis was employed for the visual data, it was also used to analyse the data from the semi-structured interviews. The same analysis approach was utilised so that the data "can be analysed to capture and interpret the holistic integrity" of the case study (Buchanan, 2012, p. 362).

In doing the thematic analysis, the researcher uses some grounded theory principles (Corbin \& Strauss, 2008 , including coding and constant comparison. Some of the data generated from the drawing and photographs technique will be examined in the next section.

\section{FINDINGS AND DISCUSSION}

Although the focus of this paper is on the visual methods, some data from the interviews will also be presented. This will help the assessment of the value of visual methods compared to other methods such as the interviews.

\subsection{Images as the Catalyst to Stimulate Responses}

Previously, we were like ducks in the muddy water; all employees looked the same [muddy]. With the modernisation ${ }^{4}$ or the clean water, the white ducks which used to look muddy have started to look clean. Well, the black ones look black, still look black. There are naughty employees; those whom I mean as the black ducks.

Using the 'lake water', 'white' and 'black ducks' to represent the reform, clean and corrupt employees, respectively, the above quotation nicely describes the issue being researched in this study. The quote is a narrative of a drawing by one participant of this study. The reform is perceived as clean water which has changed the muddy ducks into white ducks. Muddy ducks represent corrupt employees, while white ones represent the clean employees.

While showing her picture to the other members of the focus group discussion, the participant who produced the duck image went on saying, "Here is the leader. We need a leader. We depend on the leader." She drew the leader as the duck with a crown, leading the other ducks.

This particular participant was a quiet member of the group and rarely involved in the group discussion. Even when she was asked to explain or clarify her statement, she spoke shyly. Hence, her picture is able to clearly depict the connection between the reform and corruption in the organisation, and also the importance of leadership, in the same frame. Later in the group discussion, other participants referred to the term used in her image, like 'naughty' employees (i.e., those officials who were actively involved in corrupt acts prior to the reform). These findings show the ability of images to stimulate responses.

Thus, the advantage of using a drawing technique is that everybody, even a quiet person, has a chance to talk in the group and express his/her view using the image that has been produced. The ability of images to stimulate responses also appears in the individual interviews, following the photograph sessions. Feedback from the photograph participants reveals that images facilitate them in expressing their views. For the photograph participants, images have helped them in expressing their views on the topic, as the pictures could expand the (verbal) story. Verbal explanation, on the other hand, is also helpful to clarify the meaning of the images. Therefore, pictures play the role of a catalyst for individual talks as well as for group discussions (Ward, 2009).

The theme of reduction in corruption did not just emerge from the images. It was also confirmed by many participants of the semi-structured interviews, who reported that the reform had significantly reduced

\footnotetext{
${ }^{4}$ The tax administration reform is also known to the employees as the 'modernisation'.
} 
corruption in the organisation. The confirmatory role of visual data will be explained in the following section.

\subsection{The Confirmatory Role of Visual Data}

It is interesting to find how participants, both from the interviews and visual methods, were talking about corruption without mentioning the word 'corruption'. A couple of quotes from the interviews are presented below, to show the confirmatory role of visual data to other data such as the interviews (Kearney \& Hyle, 2004). The terms used, i.e., 'white', 'black', 'naughty', are similar to those emerging from the visual data.

There has been a very significant change. Yes, extremely significant... many of them have changed. Those whom we used to know as 'very naughty' became much lessened. Those who used to be 'just naughty' became 'not naughty'.

On a scale of 1 until 100, before the reform, it can be said that the 'white' was $20 \%$ of the employees, the 'black' was $20 \%$ and the rest were 'grey'. 'Grey' means, erm, they might, erm, they would perform that 'action' because, not because of their willingness, but because of the, because of the environment, whether it was a command, whether it was because of their positions. Well, after we are 'modern', the $60 \%$ portion, the 'grey', necessarily becomes 'white'.

Data from both visual and the interviews show that the reform has reduced corruption in the organisation. Nevertheless, despite the positive change in corruption as the result of the reform, the black ducks or 'players' (as termed by the interview participants) still exist. This is again confirmed in both visual and interviews data, which shows the confirmatory role of the visual data to the verbal ones (Kearney \& Hyle, 2004).

The narrative of the drawing:

... Well, the black ones look black, still look black. There are naughty employees; those whom I mean as the black ducks.

\section{The interview transcript:}

There are players, who have the habits of doing negative things. However, indeed, I heard that the number has reduced, but they are still there.

The persistent black ducks did affect the change initiative. After the significant changes, the occurrence of post-change corruption, which had been widely reported by the media, was believed by many participants had unfavourable impacts and triggered emotional reactions. The reactions are depicted both in the interviews and images. The next section will elaborate on this issue.

\subsection{Drawing Out Paradoxical Emotions}

For the interview participants, the post-reform corruption incidents were viewed as an 'explosion' or 'tsunami' which ruined the organisation, the change process and the good image of the organisation which had been built up for years after the reform. It has decreased the 'trust' of the taxpayers and society in the organisation. The corruption cases also psychologically affected the employees, who felt 'painful', 'sad', 'shocked', 'betrayed' and 'demotivated'. Some interviewees perceived that it was difficult and would take a long time to 'heal the wound'. All these issues are believed to have hampered the change initiative.

Nevertheless, some interviewees held the 'halffull glass' view. They perceived the emergence from the corruption cases during the reform era as the positive impact of the change initiative, i.e., as the result of 'cleaning up' done by the organisation. Some participants positively viewed the incident as an 'eyeopener' and stated that lessons had been learned from it. These include indications of 'holes' in the reform program, the experience to handle crises and the need to sustain continuous change.

Some interview participants asserted that although the corruption cases had unfavourably impacted the change effort and made the change seems meaningless, the change must not stop. This view was echoed by a visual participant, who drew a nonstopping sign (Figure 1) and explained:

In the middle of the journey, we may want to stop, but when we see this sign, I hope we could keep our spirit up. Stopping is prohibited. The modernisation must keep going, regardless of the challenges and consequences.

Figure 1. No Stopping!

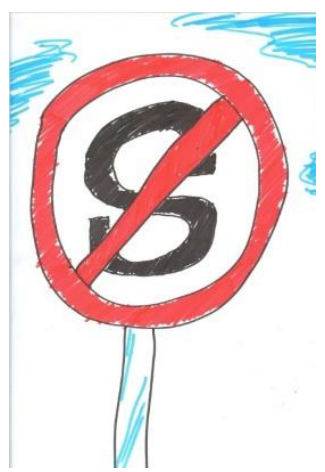

The mixed messages from different interview participants, as explained in the previous paragraphs, are captured in one frame by a visual participant (see Figure 2), who said that

I feel like being stabbed in the back! We have gone through a long and winding road. Reaching this achievement is not an easy journey....so, when someone betrays us, he or she drags us miles back. He or she pulls us almost into the start line. Oversimplification and generalised opinion are common in Indonesia. If one or some tax officers are corrupt, 
people think that all of us are deceitful officers. Every time tax service servants get caught over a corruption case, we feel a huge setback. I have many reasons to be pessimistic, but I refuse to give up. I keep on smiling instead and moving forward. There will always be corruption cases among us, but I have much more reasons to be optimistic.

Figure 2. Backstabbing: Paradoxical Emotions

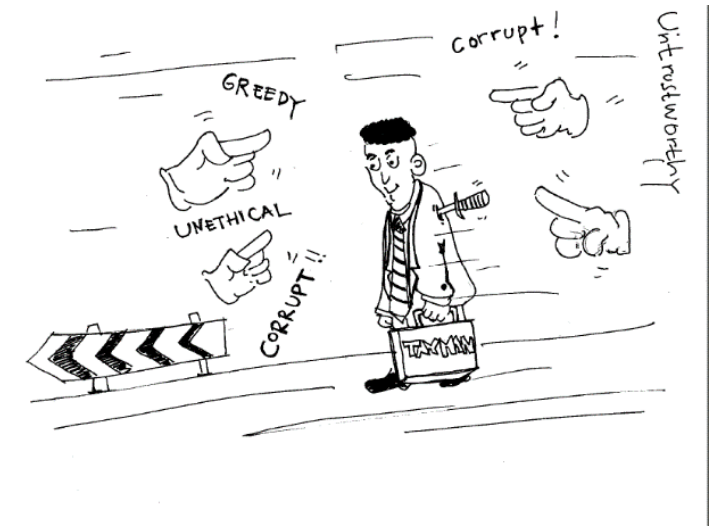

Similar to the previous images, Figure 2 shows the confirmatory role of visual to the interviews data (Kearney \& Hyle, 2004). However, there are other values of visual data shown in Figure 2, i.e., the ability to convey complex ideas and draw out paradoxical emotions (Vince \& Broussine, 1996). One still image created by one person is able to depict different ideas mentioned by different interviews participants, with regards to the impacts of corruption on the change initiative. Corruption, which occurred after the reform, was perceived as both detrimental and beneficial in sustaining the change effort. At the same time, the image in Figure 2 is powerful in describing the paradoxical emotions of the participant as the response to the post-change corruption cases. It was painful to him, yet he kept smiling and moving forward.

Interestingly, the 'long and winding road' as mentioned in the narrative of Figure 2 was a common theme drawn by participants in one of the focus groups. This leads to another discussion on another power of visual data.

\subsection{Unveiling the 'dark side'}

Figure 3. The Long and Winding Road

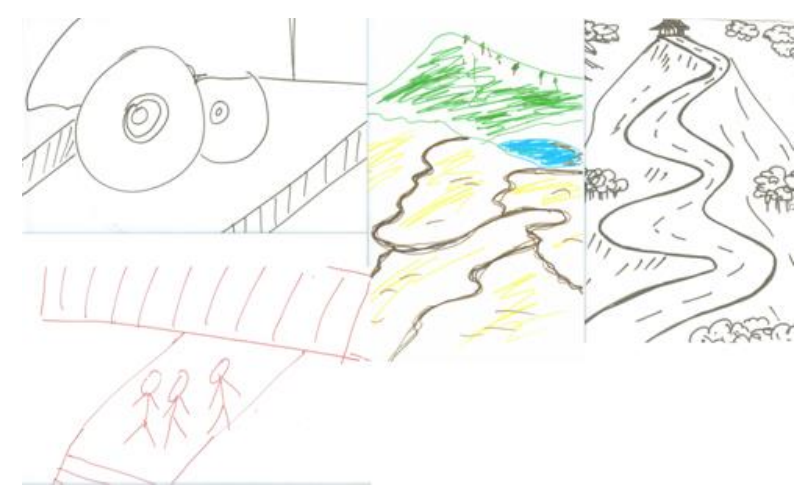

In one of the focus groups, most of the group members depicted the reform as a 'journey' and mentioned about the 'long and winding road' to describe obstacles that were encountered along the way. Some examples of these drawings can be seen in Figure 3. In the other group, however, the images and discussions focused more on other issues than the change journey. Despite the differences between the two focus groups, a similar pattern of response emerged. A couple of images did show smiling faces, depicting pride or gladness, however, in general, what mostly came out from the drawings were issues such as obstacles, disappointments or expectations related to the change and/or corruption in the organisation. In stating their expectations, the participants explicitly and implicitly said that the expectations had not been fully met. A few examples will be presented below.

The first example can be seen in Figure 4. The two images were drawn by two different participants, i.e., two staff members from the first group. Despite having different images, they convey similar messages. The images depict: (a) the perceived weak law enforcement (as described by the blunt or upside-down knife as well as the frowning face), since more attention is perceived being paid to enhancing taxpayers' services (the smiling face) and; (b) the expectation that reforming the tax administration is not about reforming DGT per se, but also reforming other related parties or institutions, so that "DGT does not walk alone".

Figure 4. An upside-down knife and a crossroad
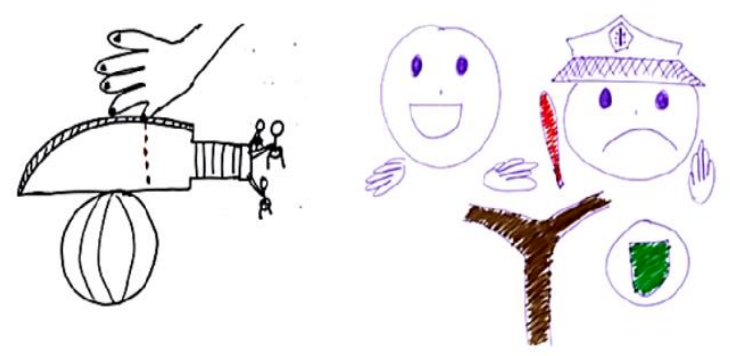

Another example is presented in Figure 5. The image shows the expected conditions from the reform, which are perceived could impact on employees' pride. Some of the conditions are wireless offices and integrated databases (the connected computers' image); transparent, consistent, fair relocation policies (the Indonesian map image); health insurance for employees and families (the hospital image); as well as fair and unbiased rules (the blindfolded goddess of justice image). However, the existing gap between the expectations and reality has not arisen pride among the employees. 
Figure 5. \#DGTproud

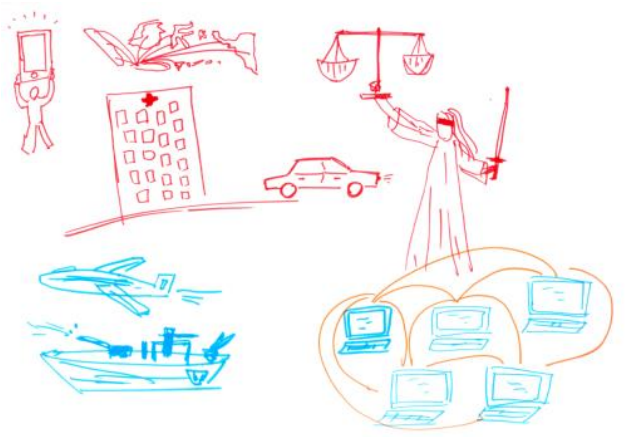

Similar to Figure 5, which was produced by a staff member, the theme of 'lost expectation' also emerged from the middle managers group (Figure 6). The manager drew the smiling, straight and angel faces to depict his feelings at the beginning of the reform, after the reform had taken place and his hopes for the future, respectively. Despite expressing his positive response and high expectation at the beginning of the reform (the smiling face), as well as his appreciation on the improvement after the reform, the participant maintained that the images represented his confusion, hesitation and doubt, as he felt uncertain about the reform. His explanation and the group discussion indicate that the issues causing his concern were role models, and reward and punishment. The issue of corruption also arose, although he admitted that he did not have any evidence, as it was based only on a story he had heard. In his drawing, he depicted his uncertain feeling of the reform with the lightning and airflow image.

Figure 6. Lost expectation

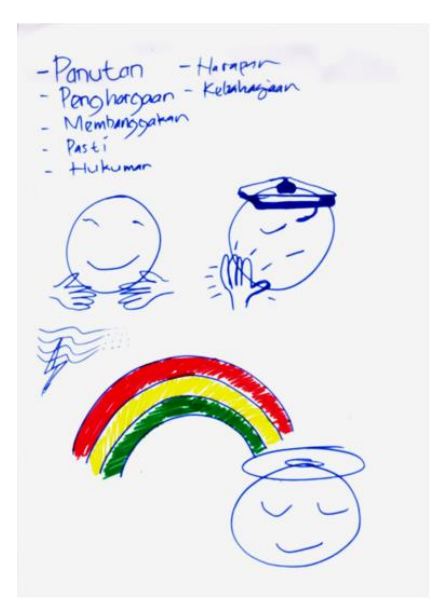

These kinds of responses, which emerged from the images, are different from what was found in the interviews. Although some interview participants also commented on the problems in the reform, they balanced it out by telling more positive accounts, such as significant changes or better conditions after the reform, which did not really appear in the drawings. It seems that the drawing method tends to reveal participants' views on the 'dark side' of the reform. Perhaps, this demonstrates the potential ability of the drawing method in unveiling such an account.
In addition to the values of visual methods as mentioned earlier, there is one more advantage that will be explained in the next section.

\subsection{Retaining the Original Thought}

From the review stage at the end of the drawing sessions, it has been found that the drawings are useful during the group discussions, as they help make the discussions more focused. Participants explained the usefulness of the drawings in representing the original thoughts or ideas of the focus group members. During the group discussion, there is a possibility that people may lose their original thoughts on the topic being discussed, as they hear or respond to other people's ideas during the discussion. Being asked to draw out or write down their thoughts at the beginning of the group discussion helps the participants to retain their original thoughts to be shared later with the group. However, being asked to draw can be a challenge for some people. It arises a question: how do we manage resistance to draw?

\section{6. 'I cannot draw': Managing Resistance to Draw}

As suggested in the literature (Broussine, 2008; Kearney \& Hyle, 2004; Vince \& Warren, 2012; Ward, 2009), the downside of visual methods is the possibility of resistance to drawing from the participants. Interestingly, this study encountered more (initial) resistance to drawing from the second group, which consisted of middle managers. Half of the group verbally expressed their reluctance, by saying that they were not good at drawing, or had no idea what to draw. One of them was the manager who drew Figure 6. He had initially had difficulty in visualising his thoughts. He took longer than the rest of the group to finish his drawing. He was eventually able to produce his picture after getting the idea from 'emoticons'.

In handling the resistance, the researcher convinced them that it was not a drawing competition, so they did not need to worry about the quality of the drawings, but it did not seem to help reduce the resistance. The researcher then allowed them to write some keywords on the paper, as they still had difficulty with drawing (see examples of the words in Figure 6, in which the participants wrote: 'role model', 'rewards', 'proud', 'certainty', 'punishment', 'expectation', 'happiness'). The rest of the participants, who did not have a similar problem, wrote the keywords after they had finished drawing. Using this strategy, eventually, all participants were able to finish and show their pictures, although a few participants still had a little concern about how their drawings looked.

The drawback of drawing was acknowledged by the participants. There was a concern that the drawing method does not suit everyone. It may fit the visual people better than the other types. For example, one participant, who was not a visual type of person, gave feedback during the review stage that he was initially confused when asked to draw and had difficulty visualising his views or feelings. However, he admitted 
that being allowed to write a few words on the paper did help him, as eventually, he was able to produce an image. Therefore, there is a suggestion to consider the type of participants before applying the method.

\subsection{Verbal Explanation}

Another drawback of the visual methods is that an image cannot represent everything (views or feelings on a particular topic); thus, it needs to be explained verbally. In this study, participants were given chances to verbally explain their images to the group (for the drawing method) or in individual interviews (for the photographing technique). As stated by the photograph participant, the verbal explanation is helpful for her to clarify the meaning of the images. However, if the study could have been done differently, we would have followed up the group discussion with some individual interviews, to give more opportunities to the individuals to explain things related to the topic but not captured in the drawings. As evidenced by this study, there were potential of missing the details if we relied solely on the visual methods in collecting the data. The next section will explain the issue in more detail.

\subsection{Potential of missing the details}

Indeed, compared to the interviews data, there are some details from the interviews which are not captured in the drawings. This means, if drawing was the only method used in gathering the data, there was the possibility of losing some of these details. For example, the 'grey' colour emerged from the interviews, but not from the drawing. 'Grey' represents those who engaged in corrupt practices in the past because they were forced to do it, not because of their own willingness. The interview participants also reported the change in the magnitude of corruption. In the past, corruption was perceived as 'massive' and 'systemic', involving 'cliques' or the so-called 'congregation corruption' at virtually all levels of the organisation. However, after the reform, with the structural, technological, cultural and remuneration changes in the organisation, corruption becomes more 'individual' and 'limited'. This finding shows that the reform has not only reduced corruption but also shifted the nature of corruption from systemic to individual. These themes, however, did not emerge from the visual data.

Another theme from the interview data which was not mentioned by the visual participants was corruption because of 'need' and 'greed', which were linked to the grey and black groups, respectively. The terms were not just used by interviewees to categorise employees' involvement in corruption, but also to explain the reasons for it. It is believed that most of the corruption cases in the past were committed due to corruption by needs, which among other things is caused by low salaries. Other information on the perceived causes of the reduction in corruption as well as the occurrence of corruption cases after the modernisation were reported by the interview participants, but not by the visual respondents. Therefore, with regards to the drawbacks of using visual methods, in addition to resistance to draw, there is the potential of losing data when the visual method is not complemented with other methods. Lastly, the next section will highlight the importance of framing the instruction to produce images, especially in the photograph technique.

\subsection{Framing the Instruction}

Unlike the drawings, there were virtually no metaphors or imagination in the photographs. The photos were mostly of static banners and posters around the tax offices which visually represented some of the changes in the organisation, such as reinforcements of upholding integrity, applying organisational values, as well as the vision, mission and cultural programme.

The main theme to emerge from the photographs (although not from all photos) was maintaining integrity. Issues under this theme included visual reinforcement, refusing gratuities, the use of technology in preventing manipulation of attendance time and the use, or lack of use, of the whistleblowing system.

Figure 7. Welcome to an anti-corruption area

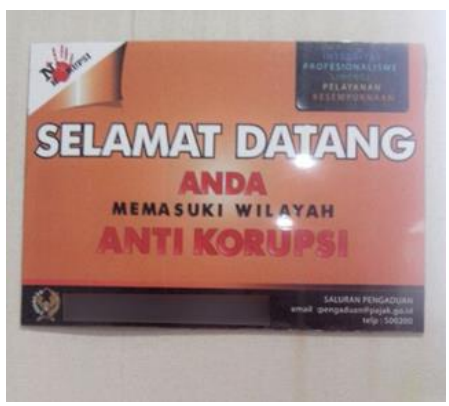

Visual media, such as standing banners and posters, frequently appeared in the photographs. Most showed the organisation's efforts to reinforce the value of integrity to its employees. They were also seen as messages to external parties, such as taxpayers, on the organisation's efforts to maintain integrity. A couple of photographs can be seen in Figure 7 and Figure 8 . In order to maintain the anonymity, the parts of the pictures with signatures, individual names, as well as the office's name, are obscured.

The instruction given to participants was to take photographs which described their views on the reform and/or corruption in the organisation. Participants gave different responses to the instruction. One participant found it challenging to capture corruption in photographs because he thought it was an abstract issue to be captured. Perhaps, we need to rephrase the instruction so that it did not sound too abstract for the participants. As in the drawing method, there is a lesson learned that phrasing the wording for the instruction is essential in the photograph method as well. 
Figure 8. Signing up to the 'Clean DGT' declaration

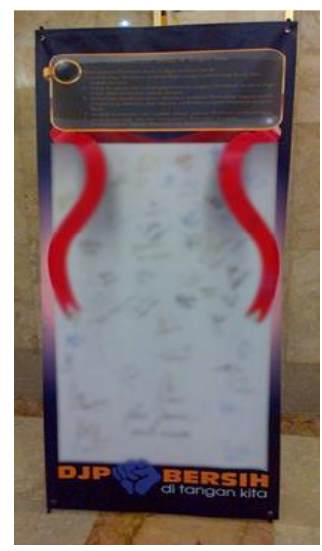

However, the other participant did not appear to have an issue. This may have been because of her experience of dealing with gratuities, as discussed in the individual interviews. Nonetheless, the participant realised that it might depend on the person. She thinks that the reason she did not have a problem with the method, maybe because she is a visual person and quite likes taking pictures. Again, this resonates with the feedback of the drawing method, i.e., that the visual methods, either drawing or photograph, may fit the visual people better than the other types.

\section{CONCLUSION}

The use of visual methods in this article has provided an alternative way to study tax reform and corruption. This article supports the existing literature on the power of images in stimulating responses as well as the confirmatory role of visual data to other data such as the interviews. The evidence also confirms the ability of pictures to draw out paradoxical emotions towards organisational change and convey complex ideas in one still image. Additionally, compared to the interviews data, the visual data do not provide many accounts of the significant changes or better conditions after the reform. It seems that the drawing method tends to reveal participants' views about the 'dark side' of the organisational change and its management. This shows the potential power of the drawing method in unveiling such accounts.

However, despite these advantages, it is evident in this study that there is a possibility of losing the detail when images cannot capture what can be captured by other methods such as the interviews. Perhaps, this is because it is quite challenging to put all of one's views onto a piece of paper. Also, it might be because of the limited time that each participant had to comment on the image in a focus group. It does not necessarily mean that a focus group is not an appropriate approach to use with visual methods. However, combining or following up visual methods with other research methods such as semi-structured interviews would be advisable.

A few recommendations can be made on the use of visual methods. This study has found greater resistance to drawing by middle managers than by the group of junior staff members. Future research might be conducted to understand whether age and organisational roles affect participants' resistance to drawing. In addition, as some details of the interviews could not be captured in visual data, following up the group discussion with individual interviews is recommended for future research. This will allow the researcher to obtain richer details, or 'properties', in Corbin \& Strauss' (2008) term, and fuller understanding of the phenomenon under study.

\section{REFERENCES}

Allen, L. (2011). 'Picture this': using photo-methods in research on sexualities and schooling. Qualitative Research, 11(5), 487-504.

Barner, R. (2008). The dark tower: Using visual metaphors to facilitate emotional expression during organizational change. Journal of Organizational Change Management, 21(1), 120-137.

Bell, E., Bryman, A., \& Harley, B. (2018). Business research methods ( $5^{\text {th }}$ ed.). Oxford : Oxford University Press.

Bridi, A. (2010). Corruption in tax administration. Transparency International U4 Anti-Corruption Research Centre. U4 Expert Answer (January). Available online at http://www. u4.no/publications/corruption-in-taxadministration.

Broussine, M. (2008). Drawing and art. In M. Broussine (Ed.), Creative methods in organizational research (pp. 70-91). London: SAGE Publications.

Buchanan, D. A. (2012). Case studies in organizational research. In G. S. a. C. Cassell (Ed.), Qualitative organizational research: core methods and current challenges (pp. 351-370). London: SAGE Publications.

Corbin, J., \& Strauss, A. (2008). Basics of qualitative research: techniques and procedures for developing grounded theory ( $3^{\text {rd }}$ ed.). London: SAGE Publications.

Creswell, J. W., \& Creswell, J. D. (2017). Research design: Qualitative, quantitative, and mixed methods approaches ( $5^{\text {th }}$ ed.). London: SAGE Publications.

Eilam, G., \& Shamir, B. (2005). Organizational change and self-concept threats: A theoretical perspective and a case study. The Journal of Applied Behavioral Science, 41(4), 399-421.

Eisenhardt, K. M., \& Graebner, M. E. (2007). Theory building from cases: Opportunities and challenges. Academy of Management Journal, $50(1), 25-32$.

Fjeldstad, O.-H. (2005). Corruption in tax administration: Lessons from institutional reforms in Uganda. CMI Working Paper No. 10. Bergen: Chr. Michelsen Institute.

Fjeldstad, O. H. (2003). Fighting fiscal corruption: lessons from the Tanzania Revenue Authority. Public Administration and Development: The 
International Journal of Management

Research and Practice, 23(2), 165-175.

Kaufmann, D. (1997). Economic corruption: some facts. Paper presented at the 8th International AntiCorruption Conference, Lima, in which a compelling analysis of this issue is argued.(http://www. transparency. org/iacc/8th_iacc/papers/kaufmann. html).

Kearney, K. S., \& Hyle, A. E. (2004). Drawing out emotions: The use of participant-produced drawings in qualitative inquiry. Qualitative Research, 4(3), 361-382.

Meyer, A. D. (1991). Visual data in organizational research. Organization Science, 2(2), 218-236.

Packard, J. (2008). 'I'm gonna show you what it's really like out here': The power and limitation of participatory visual methods. Visual Studies, 23(1), 63-77.

Pink, S. (2013). Doing visual ethnography ( $3^{\text {rd }}$ ed.). London: SAGE Publications.

Rizal, Y. (2011). Lessons from Indonesian tax administration reform phase 1 (2001-2008): Does good governance matter. In S. Kimura, A.B. Javier, and \& A. Tangsupvattana (Eds.), Limits of good governance in developing countries (pp. 363-412). Yogyakarta, Indonesia: Gadjah Mada University Press.

Saunders, M., Lewis, P., \& Thornhill, A. (2012). Research methods for business students (6th ed.) Harlow: Pearson Education.

Shortt, H. L., \& Warren, S. K. (2019). Grounded visual pattern analysis: Photographs in organizational field studies. Organizational Research Methods, 22(2), 539-563.

Tanzi, V. (1998). Corruption around the world: Causes, consequences, scope, and cures. Staff Papers, 45(4), 559-594.

Tracy, S. J. (2019). Qualitative research methods: Collecting evidence, crafting analysis, communicating impact ( $2^{\text {nd }}$ ed.). Hoboken: John Wiley \& Sons.

Vince, R., \& Broussine, M. (1996). Paradox, defense and attachment: Accessing and working with emotions and relations underlying organizational change. Organization Studies, 17(1), 1-21.

Vince, R. and Warren, S. (2012). Participatory visual methods. In G. Symon and C. Cassell (Eds.). Qualitative organizational research: core methods and current challenges (pp. 275-295). London: SAGE Publications.

Ward, J. (2009). Managing emotions: an enquiry into some psychological and sociological aspects of affect and emotion at work. University of York.

Warren, S. (2002). Show me how it feels to work here: using photography to research organizational aesthetics. Ephemera, 2(3), 224-245.

Warren, S. (2009). Visual methods in organizational research. In D.A. Buchanan and A. Bryman (Eds.). The SAGE handbook of organizational research methods (pp. 566-582). London: SAGE Publications.

Weber, S. (2008). Visual images in research. In J.G. Knowles and A.L. Cole (Eds.). Handbook of the arts in qualitative research: perspectives, methodologies, examples, and issues (pp. 4255). London: SAGE Publications.

Wihantoro, Y. (2012). Understanding cultural aspects of bureaucratic reforms: the case of Indonesian public institutions. Aston University.

Yin, R. K. (2009). Case study research: design and methods ( $4^{\text {th }}$ ed.). London: SAGE Publications.

Zuleta, J. C. (2008). Combating Corruption in the Revenue Service: The Case of VAT Refunds in Bolivia. U4 Brief, 2008(14). 